FINANCIAL: Jurnal Akuntansi

Published by Program Studi Akuntansi STIE Sultan Agung Volume 6-Nomor 1, Juni 2020, (HIm 105-116)

ISSN-P: 2502-4574, ISSN-E: 2686-2581

Available online at: https://financial.ac.id/index.php/financiaI

\title{
ANALISIS PENGARUH KINERJA KEUANGAN TERHADAP STRUKTUR MODAL PADA PERUSAHAAN MAKANAN DAN MINUMAN YANG TERDAFTAR DI BURSA EFEK INDONESIA (BEI) PERIODE 2016-2018
}

\author{
Brigitha Yulita Hoar Bau ${ }^{1)}$, YuniatinTrisnawati D.K.W ${ }^{2)}$ \\ 1,2Program Studi Akuntansi, STIE Adi Unggul Bhirawa Surakarta, Indonesia \\ E-mail: ${ }^{1}$ thabau15@gmail.com, ${ }^{2}$ yuniatintrisnawati@gmail.com
}

\begin{abstract}
Abstrak
Penelitian ini dilakukan untuk mengetahui pengaruh likuiditas, ukuran perusahaan, struktur aktiva dan pertumbuhan penjualan pada struktur modal di perusahaan makanan dan minuman yang terdaftar di Bursa Efek Indonesia (BEI). Periode yang diteliti selama 3 (tiga) tahun yaitu dari tahun 2016-2018. Penelitian dilakukan dengan pendekatan kuantitatif dengan data populasi sebanyak 78 perusahaan makanan dan minuman yang terdaftar di BEI. Teknik pengambilan sampel menggunakan teknik purposive sampling dan diperoleh sampel sebanyak 13 perusahaan. Teknik analisis data menggunakan analisis regresi linear berganda. Hasil penelitian menunjukkan bahwa variabel likuiditas berpengaruh negatif dan tidak signifikan terhadap struktur modal, ukuran perusahaan berpengaruh negatif dan signifikan terhadap struktur modal, sedangkan variabel struktur aktiva dan pertumbuhan penjualan berpengaruh positif dan signifikan terhadap struktur modal.

Kata kunci: Struktur Modal, Likuiditas, Ukuran Perusahaan, Struktur Aktiva, Pertumbuhan Penjualan
\end{abstract}

\section{ANALYSIS EFFECT OF FINANCIAL PERFORMANCE OF CAPITAL STRUCTURES AT FOOD AND BEVERAGES COMPANY REGISTERED ON INDONESIA STOCK EXCHANGE (IDX) PERIOD 2016-2018}

\begin{abstract}
Abstrack
This research was conducted to determine the impact of liquidity, company size, asset structure and sales growth of the capital structure in food and beverage companies listed on the Indonesia Stock Exchange (IDX). The period is 3 (three) years from 2016-2018. This research uses a quantitative approach. The population consist of 78 food and beverage companies listed on the IDX. Sampling techniques used purposive sampling techniques and obtained as many as 13 companies. Multiple linear regression analyses used data analysis techniques. The results of this study showed that the liquidity variables were negatively and insignificant to the capital structures and the company size variables were negatively and significantly influential towards the capital structure. While variable asset structure and sales growth have positive and significant effect on the capital structure.
\end{abstract}

Keywords: Capital structure, liquidity, company size, asset structure, and sales growth

Article History: $\quad$ Received: 30 Apr 2020 Revised: 14 Mei 2020 Accepted: 29 Mei 2020 


\section{PENDAHULUAN}

Struktur modal selalu menjadi topik yang cukup menarik untuk dikaji dan diteliti lebih lanjut, karena berkaitan dengan keputusan pendanaan suatu perusahaan, terutama perusahaan makanan dan minuman. Keputusan pendanaan merupakan salah satu keputusan yang sangat penting yang harus dihadapi oleh manajer keuangan dalam kaitannya dengan kegiatan operasi perusahaan. Keputusan pendanaan yang baik selalu dilihat dari struktur modal perusahaan. Keputusan manajer keuangan selalu berkaitan dengan komposisi utang yang akan digunakan oleh perusahaan, baik utang jangka panjang, utang jangka pendek, saham biasa dan saham preferen. Struktur modal merupakan topik yang komplek dan juga merupakan salah satu faktor yang menentukan nilai perusahaan (Liem, Sutejo, Muhardi, 2013). Struktur modal didefinisikan sebagai komposisi perbandingan antara modal perusahaan yang dilihat dari utang dan dari modal pemilik (Rasyid, 2015). Struktur modal yang optimal adalah dengan menggabung sumber-sumber dana yang digunakan oleh perusahaan dalam membiayai kegiatan operasi perusahaan sehingga dengan pengabungan dana dapat meminimalkan biaya modal dan memaksimalkan harga saham (Ahmad Rodoni dan Herni Ali, 2010).

Perusahaan yang memiliki analisis informasi struktur modal yang baik akan membuat investor untuk menanamkan modal, maka struktur modal memiliki peran yang sangat penting dalam perusahaan karena baik buruknya suatu perusahaan hanya dapat dilihat dari laporan struktur modal dalam bentuk laporan keuangan pada setiap periode. Struktur modal diukur dengan debt to Copyright (C) 2020, FINANCIAL: Jurnal Akuntansi equity ratio, yaitu rasio yang digunakan untuk mengukur penggunaaan utang terhadap total modal sendiri yang dimiliki oleh suatu perusahaan (Riyanto, 2011).

Beberapa faktor kinerja keuangan yang digunakan untuk mengetahui pengaruhnya terhadap struktur modal yaitu Likuiditas, Ukuran Perusahaan, Struktur Aktiva dan Pertumbuhan Penjualan.Kinerja merupakan strategi perencanaan (strategic planning) suatu perusahaan tentang tingkat pencapaian pelaksanaan kegiatan operasi perusahaan untuk mewujudkan sasaran, tujuan, misi dan visi suatu organisasi perusahaan. Prestasi kerja yang dicapai oleh sebuah perusahaan, sering di artikan sebagai kinerja keuangan yang tercermin dalam laporan keuangan perusahaan tersebut. Pengukuran kinerja keuangan dapat dilakukan dengan penilaian serta analisis laporan keuangan.

Menurut penelitian Lestari \& Purnawati (2018) serta Gunadhi \& Putra (2019), Likuiditas berpengaruh negatif dan signifikan terhadap Struktur Modal. Sedangkan penelitian Wirawan (2017) menyatakan bahwa Likuiditas berpengaruh negatif dan tidak signifikan terhadap Struktur Modal.

Menurut penelitian Wirawan, (2017), Lestari \& Purnawati (2018), serta Andika \& Sedana (2019), ukuran perusahaan berpengaruh positif dan signifikan terhadap struktur modal. Sedangkan penelitian Nurhayati, et.al (2019) menyatakan bahwa ukuran perusahaan memiliki pengaruh negatif dan tidak signifikan terhadap struktur modal.

Penelitian Gunadhi \& Putra, (2019), Wulandari \& Artini (2019) serta Setiyanti et.al (2019) menyatakan bahwa pertumbuhan penjualan memiliki pengaruh 
yang positif dan signifikan terhadap struktur modal. Sedangkan penelitian Prabowo et.al (2019), menyatakan bahwa pertumbuhan penjualan berpengaruh negatif dan tidak signifikan terhadap struktur modal.

Menurut Andika \& Ida Sedana (2019) serta Wirawan (2017), struktur aktiva berpengaruh positif dan signifikan terhadap struktur modal. Sedangkan menurut penelitian Prabowo et.al (2019), struktur aktiva berpengaruh negatif dan tidak signifikan terhadap struktur modal.

Penelitian ini dilakukan karena terdapat berbagai research gap yang terjadi antara beberapa peneliti dengan hasil yang berbedabeda. Rumusan masalah yang disusun adalah : 1). Apakah Likuiditas berpengaruh signifikan terhadap struktur modal pada perusahaan makan dan minuman yang terdaftar di BEI periode 2016-2018, 2). Apakah ukuran perusahaan berpengaruh signifikan terhadap struktur modal pada perusahaan makan dan minuman yang terdaftar di BEI periode 2016-2018?, 3). Apakah struktur aktiva berpengaruh signifikan terhadap struktur modal pada perusahaan makan dan minuman yang terdaftar di BEI periode 2016-2018?, 4). Apakah pertumbuhan penjualan berpengaruh signifikan terhadap struktur modal pada perusahaan makan dan minuman yang terdaftar di BEI periode 2016-2018?

Tujuan dari penelitian ini yaitu untuk menganalisis kinerja keuangan (likuiditas, ukuran perusahaan, struktur modal dan pertumbuhan perusahaan) terhadap struktur modal.

\section{LANDASAN TEORI}

$\begin{array}{ccc}\begin{array}{c}\text { Menurut } \\ \text { mendefinisikan }\end{array} & \begin{array}{c}\text { Mulyadi } \\ \text { pengertian }\end{array} & \begin{array}{c}(2007: 2) \\ \text { kinerja }\end{array} \\ \text { Copyright } \text { (C) 2020, FINANCIAL: Jurnal Akuntansi }\end{array}$

keuangan merupakan penentuan secara priodik efektifitas suatu organisasi dan karyawannya berdasarkan pada sasaran, standar dan kriteria yang ditetapkan sebelumnya. Kinerja keuangan merupakan prestasi yang telah dicapai oleh suatu perusahaan pada suatu periode tertentu, dimana dapat menggambarkan kesehatan laporan keuangan perusahaan dengan indikator kecukupan modal.

Likuiditas merupakan kemampuan perusahaan dalam memenuhi kewajiban jangka pendeknya. Menurut (Kasmir, 2016:129) menyatakan likuiditas merupakan rasio yang menggambarkan kemampuan perusahaan untuk memenuhi kewajiban (utang) jangka pendek. Likuiditas diukur menggunakan current ratio (CR). Sesuai dengan packing order theory, perusahaan akan lebih mengutamakan menggunakan dana internalnya, sehingga perusahaan dengan likuiditas tinggi akan mengurangi pendanaan eksternalnya karena sudah memiliki sumber dana internalnya yang tinggi. Dapat disimpulkan bahwa, likuiditas merupakan kemampuan suatu perusahaan dalam memenuhi utang jangka pendek perusahaan dengan cara menyeimbangkan aktiva lancar dengan kewajiban lancarnya.

Ukuran perusahaan didefinisikan sebagai besar kecilnya perusahaan dilihat dari besarnya nilai equity dan nilai perusahaan ataupun hasil nilai total aktiva dari perusahaan tersebut (Riyanto, 2010:229). Semakin besar ukuran perusahaan yang diukur melalui total aset, maka perusahaan akan menggunakan utang dalam jumlah yang besar. Ukuran perusahaan yang relatif besar akan cenderung menggunakan dana eksternal yang cukup besar (Mas'ud, 2008). 
Struktur aktiva (tangibility of assets) merupakan perbandingan antara aktiva tetap dengan total aktiva yang dimiliki oleh suatu perusahaan yang menunjukkan besarnya alokasi dana untuk setiap komponen aktiva yang dimiliki perusahaan. Semakin tinggi struktur aktiva maka semakin tinggi struktur modalnya diartikan sebagai semakin besar aktiva tetap yang dijadikan jaminan utang oleh perusahaan tersebut (Chowdhury \& Chowdhury, 2012). Perusahaan dengan struktur aktiva yang rendah akan menunjukkan bahwa perusahaan tersebut memiliki tingkat kemampuan yang cukup rendah dan tidak dapat menjamin hutang jangka panjang perusahaan tersebut (Kesuma, 2009). Perusahaan yang memiliki struktur aktiva yang besar akan memiiki jaminan yang cukup atas pinjaman atau utang mereka. Semakin banyak struktur aktiva yang dimiliki perusahaan, maka semakin tinggi pula motivasi bagi kreditur menyetujui kredit tingkat hutang.

Pertumbuhan penjualan merupakan kenaikan jumlah penjualan dari tahun ke tahun atau dari waktu ke waktu (Kennedy, 2010). Perusahaan yang memiliki tingkat pertumbuhan penjualan yang semakin tinggi akan menentukan seberapa besar berhasil dalam menjalankan strategi perusahaannya. Tingginya penjualan yang dihasilkan dapat menunjukkan kinerja dari manajemen perusahaan sehingga manajemen perusahaan akan dapat memiliki nilai positif dan dianggap telah bekerja dengan cukup baik.

Semakin meningkatnya penjualan maka akan semakin meningkat pula struktur modal perusahaannya sehingga jumlah pinjaman (utang) yang didapatkan

Copyright (C) 2020, FINANCIAL: Jurnal Akuntansi akan semakin besar yang akan digunakan untuk mengembangkan perusahaan.

Hipotesis yang disusun adalah sebagai berikut :

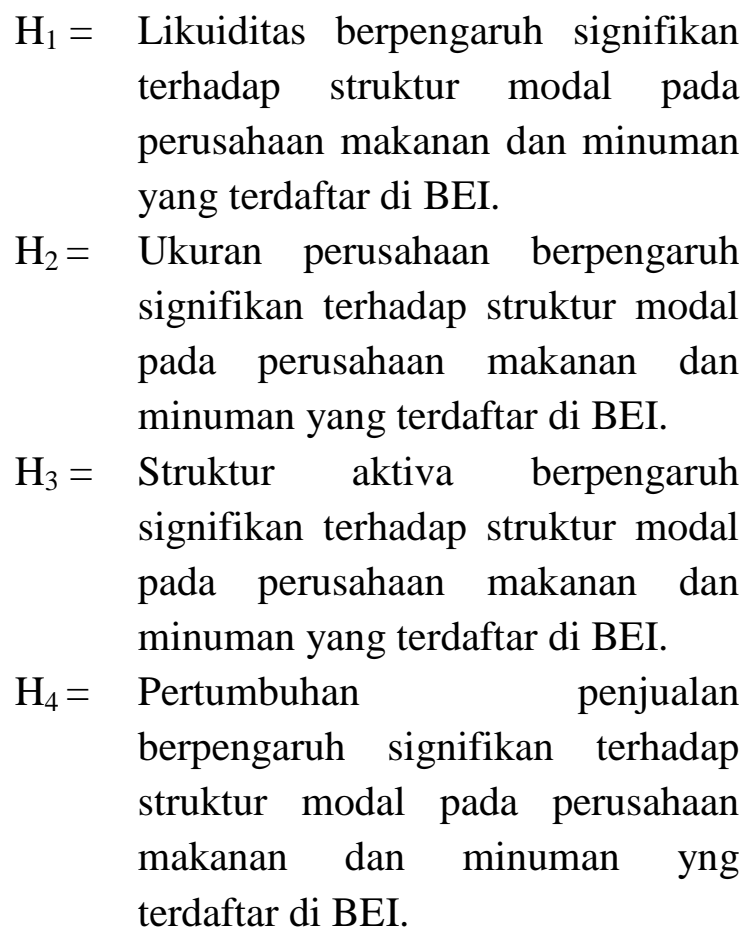

\section{METODE}

Objek penelitian adalah perusahaan sektor food and beverage yang terdaftar di BEI. Data berupa time series dengan pengamatan laporan pada periode waktu selama 3 tahun yaitu 2016-2018.

Populasi sebanyak 13 perusahaan merupakan perusahaan makanan dan minuman yang terdaftar di BEI selama tiga tahun berturut-turut yaitu: 2016, 2017 dan 2018, dimana perusahaan tersebut memiliki laporan keuangan yang lengkap dan dipublikasikan didalam Indonesia Stock Exchange (IDX).

Sampel yang digunakan adalah perusahaan makanan dan minuman yang terdaftar di Bursa Efek Indonesia (BEI) berturut-turut selama tahun 2016-2018. Pemilihan sampel dilakukan berdasarkan metode purposive sampling dan diperoleh sampel sebanyak 13 perusahaan. 


\section{Teknik Pengujian Hipotesis Variabel Dependen}

Variabel dependen atau terikatnya adalah struktur modal, dalam penelitian ini struktur modal akan diproyeksi dengan menggunakan debt to equity ratio (DER). Deb to equity ratio (DER) merupakan rasio untuk mengukur penggunaan hutang terhadap total shareholder's equity yang memiliki perusahaan (Riyanto, 2010:61). Perhitungan struktur modal dalam penelitian ini secara matematis diformulasikan sebagai berikut:

$$
(\mathrm{DER})=\frac{\text { TotalHu } \tan g}{\text { ModalSendiri }}
$$

\section{Variabel Independen}

\section{Likuiditas}

Rasio likuiditas merupakan kemampuan suatu perusahaan dalam memenuhi utang jangka pendeknya (Kasmir,2016:129). Perhitungan likuiditas dalam penelitian ini dapat diformulasikan sebagi berikut:

$$
\text { Current Ratio }=\frac{\text { AktivaLancar }}{\text { KewajibanLancar }}
$$

\section{Ukuran Perusahaan}

Ukuran perusahaan menggambarkan besar kecilnya suatu perusahaan yang dapat dilihat besarnya total aktiva, jumlah penjualan, rata-rata penjualan dan rata-rata total aktiva. Penggunaan logaritma natural karena mengingat bahwa besarnya total penjualan setiap perusahaan berbeda-beda sehingga hasilnyapun berbeda. Perhitungan ukuran perusahaan sebagai berikut:

\section{Firm Size = Ln of Total Asset}

\section{Struktur Aktiva}

Struktur aktiva (disingkat STA), diukur dengan cara membagikan hasil antara aktiva tetap dengan total aktiva (Brigham \& Houston, 2010:39). Perhitungan struktur aktiva sebagai berikut:

Copyright (C) 2020, FINANCIAL: Jurnal Akuntansi

$$
\mathrm{STA}=\frac{\text { FixedAssets }}{\text { TotalAsset }}
$$

\section{Pertumbuhan Penjualan}

Pertumbuhan penjualan perusahaan (sales growth) pada penelitian ini yaitu dengan melakukan perbandingan antara penjualan $_{(t)}$ dikurang penjualan $(\mathrm{t}-1)$ dibagi penjualan $\mathrm{t}-1$ perusahaan.Perhitungan pertumbuhan penjualan sebagai berikut:

$$
\begin{aligned}
& \text { Pertumbuhan Penjualan } \\
= & \frac{\text { Penjualan }(t)-\text { penjualan }(t-1)}{\text { Penjualan }(t-1)}
\end{aligned}
$$

\section{Teknik Analisis Data}

\section{Analisis Linear Berganda}

Analisis ini digunakan untuk mengetahui pengaruh antara variabel bebas yaitu likuiditas, ukuran perusahaan, struktur aktiva dan pertumbuhan penjualan terhadap variabel terikat struktur modal (Y), dengan rumus (Sugiyono, 2008:277):

$\mathrm{Y}=\alpha+\beta 1 \mathrm{X}_{1}+\beta 2 \mathrm{X}_{2}+\beta 3 \mathrm{X}_{3}+\beta 4+\mathrm{e}$

Keterangan:

$\mathrm{Y} \quad=$ Struktur modal

$\alpha=$ Nilai konstanta

$\beta=$ Koefisien regresi

$\mathrm{X} 1=$ Likuiditas

$\mathrm{X} 2=$ Ukuran perusahaan

$\mathrm{X} 3=$ Struktur aktiva

$\mathrm{X} 4=$ Pertumbuhan penjualan

$e=$ Error

\section{HASIL DAN PEMBAHASAN \\ Hasil Uji Statistik Deskriptif}

Sampel pada penelitian terdiri dari 13 perusahaan dengan menggunakan metode pooled dengan jumlah 13 perusahaan dikalikan periode tahun pengamatan (3 tahun), sehingga jumlah data dalam penelitian ini menjadi $13 \times 3=$ 39

Hasil statistik deskriptif menunjukkan bahwa nilai minimum variabel likuiditas sebesar 0,68 dan nilai 
maksimum sebesar 11,07 dengan nilai ratarata (mean) 2,637 pada standar deviasi sebesar 2,393 Hasil statistik deskriptif menunjukkan bahwa nilai minimum variabel likuiditas sebesar 0,68 dan nilai maksimum sebesar 11,07 dengan nilai ratarata (mean) 2,637 pada standar deviasi sebesar 2,393 Artinya setiap hutang lancar sebesar $\mathrm{Rp} 1$ dapat ditanggung oleh $\mathrm{Rp}$ 2.637 aset lancar, dan perusahaan yang memiliki rasio likuiditas terbaik adalah PT.Ultrajaya Milk Industry \& Trading Co.Tbk

Nilai minimum variabel ukuran perusahaan sebesar 568240,00 dan nilai maksimum sebesar 96537796,00 dengan nilai rata-rata $11.113 .972,89$ pada standar deviasi 24.272.181,00. Nilai minimum variabel ukuran perusahaan sebesar 568240,00 dan nilai maksimum sebesar 96537796,00 dengan nilai rata-rata 11.113.972,89 pada standar deviasi 24.272.181,00. Artinya ukuran perusahaan terbesar adalah PT. Indofood Sukses Makmur.Tbk dengan nilai sebesar 96537796,00. Nilai rata-rata Ukuran perusahaan > standar deviasi menunjukkan bahwa sebaran nilai ukuran perusahaan cukup baik

Nilai minimum variabel struktur aktiva sebesar 0,06 dan nilai maksimum sebesar 0,81 dengan nilai rata-rata 0,407 pada standar deviasi 0,182. Artinya Struktur aktiva sebesar 0,081 dimiliki oleh PT. Tri Bayan Tirta.Tbk dan rata - rata struktur aktiva pada perusahaan yang diteliti sebesar 0,407. Nilai rata-rata 0,407 $>$ standar deviasi 0, 182 menunjukkan bahwa stuktur aktiva baik.

Nilai minimum variabel pertumbuhan penjualan sebesar 262143,00 dan nilai maksimum sebesar 73394727,00 dengan nilai rata-rata $10.125 .591,49$ pada Copyright (C) 2020, FINANCIAL: Jurnal Akuntansi standar deviasi 19.829.646,51. Artinya Pertumbuhan Penjualan terbesar terdapat pada PT. Indofood Sukses Makmur.Tbk dengan nilai sebesar 73394727,00 dan terendah pada PT. Tri Bayan Tirta.Tbk dengan nilai sebesar 262143,00.

Nilai minimum variabel struktur modal sebesar 0,18 dan nilai maksimum sebesar 3,28 dengan nilai rata-rata 1,130 pada standar deviasi 0,741 . Artinya Nilai terbesar Struktur Modal pada PT. Prasidha Aneka Niaga.Tbk sebesar 3,28 dan terendah pada PT. Delta Djakarta.Tbk sebesar 0,18

\section{Uji Asumsi Klasik \\ Uji Normalitas}

Hasil uji SPSS menunjukkan nilai signifikansi sebesar 0,200. Nilai signifikansi uji Kolmogorov-Smirnov > dari 0,05 . Artinya model persamaan regresi berdistribusi normal.

\section{Uji Multikolinearitas}

Hasil uji SPSS menunjukkan nilai tolerance likuiditas sebesar 0,564, ukuran perusahaan sebesar 0,183 , struktur aktiva sebesar 0,584 dan pertumbuhan penjualan sebesar 0,180 yang menunjukkan semua nilai Tolerance > 0,10 dan nilai VIF likuiditas (1,773), ukuran perusahaan $(5,467)$, struktur aktiva $(1,723)$ dan pertumbuhan penjualan $(5,552)$ menunjukkan semua variabel memiliki VIF < 10. Artinya seluruh variabel terbebas dari multikolinearitas.

\section{Uji Heteroskedastisitas}

Hasil uji SPSS menunjukkan bahw seluruh variabel memiliki nilai signifikansi $>0,05$. Artinya tidak terdapat pengaruh antara variabel bebas dengan absolute 
residual dan tidak terdapat masalah heteroskedastisitas.

\section{Uji Autokorelasi}

Hasil uji SPSS menunjukkan bahwa nilai $\mathrm{DW}=1,151$ nilai ini dibandingkan dengan nilai tabel signifikansi $=0,05$, dengan $(n=39)$ dan jumlah variabel independen $\quad(\mathrm{K}=4), \quad \mathrm{dl}=1,273 \quad \mathrm{dan}$ $\mathrm{du}=1,722$. Karena DW terletak antara $\mathrm{d}<\mathrm{dl}<\mathrm{du}=1,151<1,273<1,722$ maka disimpulkan bahwa terdapat autokorelasi positif.

\section{Uji Regresi Linear Berganda}

Hasil uji SPSS menunjukkan bahwa model persamaan regresi linear berganda sebagai berikut:

$$
\begin{aligned}
& Y=3,445-0,016 \text { X1 -0,215 X2 + 0,421 } \\
& \mathrm{X} 3+1,613 \mathrm{X} 4+\mathrm{e}
\end{aligned}
$$

Interprestasi dari persamaan regresi linear berganda diatas adalah sebagai berikut: $\alpha=3,445$, artinya struktur modal (Y) bernilai positif apabila likuiditas, ukuran perusahaan, struktur aktiva dan pertumbuhan perusahaan konstan.

$\beta 1=$ Nilai koefisien regresi $-0,016$, menunjukkan bahwa variabel likuiditas berpengaruh negatif pada struktur modal perusahaan, artinya bila likuiditas meningkat, struktur modal akan menurun sebesar 0,016, dengan asumsi bahwa variabel lainnya konstan.

$\beta 2=$ Nilai koefisien regresi $-0,215$, menunjukkan bahwa variabel ukuran perusahaan berpengaruh negatif pada struktur modal perusahaan, bila ukuran perusahaan meningkat maka struktur modal akan menurun sebesar 0,215, dengan asumsi bahwa variabel lainnya konstan.

$\beta 3=$ Nilai koefisien regresi 0,412, menunjukkan bahwa struktur aktiva berpengaruh positif pada struktur modal perusahaan, artinya bila struktur aktiva meningkat maka struktur modal perusahaan akan meningkat sebesar 0,412, dengan asumsi variabel lainnya konstan.

$\beta 4=$ Nilai koefisien regresi 1,613 , menunjukkan bahwa pertumbuhan penjualan berpengaruh positif terhadap struktur modal perusahaan, artinya apabila pertumbuhan penjualan meningkat maka struktur modal akan meningkat dengan asumsi bahwa variabel lainnya konstan, maka struktur modal akan meningkat 1,613 .

\section{Hasil Uji t \\ Variabel Likuiditas}

Hasil uji t menunjukkan bahwa nilai signifikansi variabel likuiditas sebesar $0,421>0,05$, artinya likuiditas berpengaruh tidak signifikan terhadap terhadap struktur modal perusahaan makanan dan minuman yang terdaftar di Bursa Efek Indonesia (BEI) periode 20162018.

\section{Variabel Ukuran Perusahaan}

Hasil uji t menunjukkan bahwa nilai signifikansi $0,000<0,05$, artinya ukuran perusahaan berpengaruh signifikan terhadap struktur modal perusahaan makanan dan minuman yang terdaftar di Bursa Efek Indonesia (BEI) periode 20162018.

\section{Variabel Struktur Aktiva}

Hasil uji t menunjukkan bahwa nilai signifikansi $0,000<0,05$, artinya struktur aktiva berpengaruh signifikan terhadap struktur modal perusahaan makanan dan minuman yang terdaftar di Bursa Efek Indonesia (BEI) periode 2016-2018..

\section{Variabel Pertumbuhan Penjualan}

uji $\mathrm{t}$ menunjukkan bahwa nilai signifikansi $0,000<0,05$, artinya 
pertumbuhan penjualan berpengaruh signifikan terhadap struktur modal perusahaan makanan dan minuman yang terdaftar di Bursa Efek Indonesia (BEI) periode 2016-2018.

\section{Hasil Uji Koefisien Determinasi $\left(\mathbf{R}^{2}\right)$}

Hasil uji SPSS menunjukkan bahwa nilai adjusted $\mathrm{R}^{2}$ sebesar 0,726 atau $72,6 \%$. Artinya variable likuiditas, ukuran perusahaan, struktur aktiva dan pertumbuhan penjualan mampu menjelaskan sebesar $72,6 \%$ terhadap variabel struktur modal perusahaan makanan dan minuman yang terdaftar di BEI periode 2016-2018, sedangkan sisanya $27,4 \%$ dipengaruhi oleh faktor lainnya yang tidak diteliti pada penelitian ini.

\section{Pembahasan}

\section{Pengaruh Likuiditas Terhadap Struktur Modal}

Likuiditas (CR) berpengaruh negatif dan tidak signifikan terhadap struktur modal (DER) dengan hasil koefisien regresi sebesar $-0,016$ dan $\alpha$ $=0,421>0,05$, maka hipotesis pertama tidak terbukti. Perusahaan dengan tingkat likuiditas yang tinggi mempunyai arti bahwa perusahaan tersebut mampu memenuhi kewajiban jangka pendeknya. Perusahaan dengan tingkat likuiditasnya tinggi dan struktur modalnya rendah, maka perusahaan akan membiayai kegiatan operasionalnya dari dana internalnya dibandingkan dari utang. Pada penelitian ini, perusahaan memilih untuk menggunakan dana internal yang dimiliki dalam kegiatan usahanya tanpa mengambil hutang karena perusahaan memiliki aset lancar yang dapat digunakan dan memaksimalkan aset lancar yang dimiliki.

Hasil penelitian ini mendukung pecking order theory yang menyatakan bahwa perusahaan terlebih dahulu akan lebih memilih menggunakan dana internal untuk membiayai kegiatan operasional perusahaan.

Hal ini sejalan dengan penelitian Wirawan (2017) yang menyatakan bahwa Likuiditas berpengaruh negatif dan tidak signifikan terhadap Struktur Modal

\section{Pengaruh Ukuran Perusahaan}

\section{Terhadap Struktur Modal}

Ukuran perusahaan memiliki pengaruh negatif dan signifikan terhadap struktur modal dengan hasil koefisien regresi $-0,215$ dan $\alpha=0,000$ $<0,05$ sehingga hipotesis kedua tidak terbukti. Hasil penelitian ini kemungkinan sesuai dengan pecking order theory yang menyatakan bahwa perusahaan lebih cenderung menggunakan pendanaan yang berasal dari dana internal dibandingkan dari utang.

Investor tidak hanya melihat berdasarkan besar kecilnya ukuran perusahaan, tetapi akan memperhatikan faktor lainnya juga, seperti sifat manajemen, prospek perusahaan dan sebagainya dalam menanamkan modal maupun membeli saham.

\section{Pengaruh Struktur Aktiva Terhadap Struktur Modal}

Struktur aktiva memiliki pengaruh positif dan signifikan terhadap struktur modal (DER) dengan hasil koefisien regresi sebesar 0,412 dan $\alpha=0,000<$ 0,05 sehingga hipotesis ketiga 
diterima. Hal ini menunjukkan bahwa semakin besar struktur aktiva akan menyebabkan semakin meningkat pula struktur modal dalam perusahaan. Implikasi bagi perusahaan makanan dan minuman yaitu dapat meningkatkan investasi pada aktiva jangka panjang perusahaan.

Pemilihan jenis aktiva perusahaan akan sangat berpengaruh terhadap struktur modal perusahaan yang bersangkutan.

4. Pengaruh Pertumbuhan Penjualan Terhadap Struktur Modal

Pertumbuhan penjualan memiliki pengaruh positif dan signifikan terhadap struktur modal (DER) dengan hasil koefisien regresi sebesar 1,613 dan $\alpha=0,000<0,05$ sehingga hipotesis keempat diterima. Nilai koefisien variabel pertumbuhan penjualan menunjukkan bahwa semakin tinggi pertumbuhan penjualan, maka akan semakin besar kebutuhan dana yang diperlukan oleh perusahaan. Perusahaan yang mengalami peningkatan penjualan akan membutuhkan modal yang cukup banyak untuk mengembangkan perusahaan, dan modal yang dibutuhkan tersebut diperoleh dari pendanaan eksternal.

Kebutuhan modal yang banyak disebabkan karena ketika perusahaan melakukan investasi dalam jumlah yang tinggi akan dapat melebihi jumlah laba yang ditahan, hal ini akan menyebabkan perusahaan akan memerlukan utang yang semakin tinggi dan semakin banyak. Sesuai dengan pecking orther theory pertumbuhan penjualan memiliki hubungan yang positif terhadap keputusan pendanaan perusahaan.

Hasil ini sejalan dengan Penelitian Gunadhi \& Putra, (2019), Wulandari \& Artini (2019) serta Setiyanti et.al (2019) menyatakan bahwa pertumbuhan penjualan memiliki pengaruh yang positif dan signifikan terhadap struktur modal.

\section{KESIMPULAN DAN SARAN Kesimpulan}

Berdasarkan hasil pengujian dan analisis data, maka dapat disimpulkan bahwa:

1. Likuiditas berpengaruh negatif dan tidak signifikan terhadap struktur modal perusahaan makanan dan minuman yang terdaftar di BEI periode 2016-2018.

2. Ukuran perusahaan berpengaruh negatif dan signifikan terhadap struktur modal perusahaan makanan dan minuman yang terdaftar di BEI periode 2016-2018.

3. Struktur aktiva berpengaruh positif dan signifikan terhadap struktur modal perusahaan makanan dan minuman yang terdaftar di BEI periode 20162018.

4. Pertumbuhan penjualan berpengaruh positif dan signifikan terhadap struktur modal perusahaan makanan dan minuman yang terdaftar di BEI periode 2016-2018.

5. Nilai koefisien determinasi (Adjusted $\mathrm{R}^{2}$ ) menunjukkan bahwa variabel likuiditas, ukuran perusahaan, struktur aktiva dan pertumbuhan penjualan mampu menjelaskan $72,6 \%$ terhadap variabel struktur modal perusahaan makanan dan minuman yang terdaftar di Bursa Efek Indonesia (BEI) periode 2016-2018, sedangkan sisanya sebesar 
27,4\% dijelaskan oleh variabel lainnya seperti harga saham, kepemilikan manajerial dan profitabilitas yang tidak diteliti dalam penelitian ini.

\section{Saran}

1. Peneliti selanjutnya dapat menambahkan atau mengurangi variabel dalam penelitian ini, agar tidak hanya menggunakan variabel yang sama dalam penelitian ini. Misalnya profitabilitas, kepemilikan manajerial dan variabel lainnya.

2. Peneliti selanjutnya juga disarankan untuk menggunakan sampel perusahaan lain, selain perusahaan makanan dan minuman dengan periode yang lebih panjang sehingga hasilnya dapat digeneralisir.

3. Peneliti selanjunya juga disarankan untuk menggunakan variabelvariabel yang diduga maupun diprediksi dapat mempengaruhi struktur modal.

\section{DAFTAR PUSTAKA}

Andika, I. K. R., \& Sedana, I. B. P. (2019) Pengaruh Profitabilitas, Struktur Aktiva, Dan Ukuran Perusahaan Terhadap Struktur Modal. E-Jurnal Manajemen, 8(9), 5803-5824.

Andritani, Linda, Azis Fathoni, and Dheasey Amboningtyas. "The Effect Of Company Size, Company Age And Leverage On The Equipment Of Profitability As A Variable Mediation." Journal of Management 5.5 (2019).

Brigham. (1983). "Fundamentals of Financial Management”.Third Edition. Holt-saunders Japan: The Dryden Press

Brigham dan Houston. 2010. Dasar-dasar manajemen keuangan. Buku 1 (edisi II). Jakarta: Salemba Empat.
Brigham Eugene F., Gapenski, Louis C. 1996, Intermediate Financial Management, $5^{\text {th }}$ Ed., The Dryden Press, Florida, United State.

Bursa Efek Indonesia, Gedung Bursa Efek Indonesia,Tower 1, Lantai 6 Jl. Jend. Sudirman Kav52-53 Jakarta Selatan 12190,Indonesia, 2019 www.idx.co.id

Bursa Efek Indonesia, laporan-keuangantahunan,Jakarta,Indonesia,2019 penerbit investing.com/ www.investing.com

Chowdhury, A., \& Chowdhury, S. P. (2012). Impact of capital structure on firm's value: Evidence from Bangladesh. Business and Economic Horizons, 3(3), 5-18.

Ghozali, Imam. 2011. Aplikasi Analisis Multivariat dengan Program SPSS19. Semarang: Univ. Diponegoro.

Guna, M. A., \& Sampurno, R. D. (2018). Analisis Faktor-Faktor Yang Mempengaruhi Struktur Modal (Studi Kasus Pada Perusahaan Makanan Dan Minuman Yang Terdaftar Di Bei Periode 20122016). Diponegoro Journal Of Management, 7(2), 236-247.

Gunadhi, G. B. D., \& Putra, I. M. P. D. (2019). Pengaruh Profitabilitas, Struktur Aset, Likuiditas, Dan Pertumbuhan Penjualan Terhadap Struktur Modal Perusahaan Makanan Dan Minuman. E-Jurnal Akuntansi, 641-668.

Harris, M. dan Raviv, A. 1991.The Theory of Capital Structure.Journal of Finance,Vol. 46, No. 1, Maret: $297-$ 355.

Kartini dan Tulus Arianto. 2008. Struktur Kepemilikan, profitabilitas, pertumbuhan Aktiva, dan Ukuran Perusahaan terhadap Struktur Modal Perusahaan Manufaktur di Bursa Efek Indonesia. Jurnal Keuangan dan Perbankan. Vol 12No.1. Hlm: 11-21. 
Kasmir. (2016). Manajemen Sumber Daya Manusia (Teori dan Praktik). Depok: Rajagrafindo Persada.

Kesuma, A. (2009). Analisis Faktor yang Mempengaruhi Struktur Modal Serta Pengaruhnya Terhadap Harga Saham Perusahaan Real Estate yang Go Public di Bursa Efek Indonesia. Jurnal Manajemen Dan Kewirausahaan, 11(1), 38-45.

Lestari, N. L., \& Purnawati, N. K. (2018). Analisis Pengaruh Kinerja Keuangan Terhadap Struktur Modal Pada Perusahaan Makan dan Minuman di BEI. E-Jurnal Manajemen Unud, 7(7).

Liem, Jemmi Halim, Werner R. Murhadi dan Bherta Silvia Sutejo. (2013). Faktor-Faktor yang Mempengaruhi Struktur Modal pada Industri Consumer Goods yang Terdaftar di BEI Periode 2007-2011. Jurnal Ilmiah MahasiswaUniversitas Surabaya, 2 (1), 1-11.

Lukman Syamsudin. 2007. Manajemen Keuangan Perusahaan. Jakarta: PT. Raja Grafindo Persada

Mas'ud, M. 2008. “Analisis Faktor-faktor yang Mempengaruhi Struktur Modal dan Hubungannya terhadap Nilai Perusahaan. Jurnal Manajemen dan Bisnis. 7 (1), pp: 11-14.

Myers, S, The Capital Structure Puzle, Journal of Finance, Vol.39. July, 1984

Mulyadi. 2007. Sistem Terpadu Pengelolaan Kinerja Personel Berbasis Balanced Scorecard. Yogyakarta (ID): Unit Penerbit dan Percetakan Sekolah Tinggi Ilmu Manajemen YKPN.

Nurhayati, R., Titisari, K. H., \& Wijayanti, A. (2019, April). Ukuran Perusahaan, Struktur Aktiva, Profitabilitas Dan Struktur Modal. In Proseding Seminar Nasional Akuntansi(Vol. 2, No. 1).

Prabowo, N., Astuti, D. S. P., \& Harimurti, F. (2019). Pengaruh Profitabilitas,
Pertumbuhan Aset, Likuiditas, Struktur Aktiva, Dan Pertumbuhan Penjualan Terhadap Struktur Modal. Jurnal Akuntansi dan Sistem Teknologi Informasi, 14(3).

Premawati, I. G. A. S., \& Darma, G. S. (2019). Pengaruh Ukuran Perusahaan, Pertumbuhan Penjualan, Struktur Aktiva, Dan Profitabilitas Terhadap Struktur Modal (Penelitian Di Bursa Efek Indonesia Periode 2011-2015). Jurnal Ilmiah Akuntansi \& Bisnis, 2(2), 272-286.

Rasyid, Abdul. 2015. Effects of Ownership Structure, Capital Structure, Profitability and Company's Growth Towards Firm Value. International Journal of Business and Management Invention. Vol 4 (4).

Riyanto, Bambang. (2011). Dasar-Dasar Pembelanjaan Perusahaan, Edisi keempat, Cetak Ketujuh, BPFE, Yogyakarta.

Setiyanti, S. W., \& Prawani Sr, D. (2019). Pengaruh Profitabilitas, Ukuran Perusahaan, Struktur Aktiva Dan Pertumbuhan Penjualan Terhadap Struktur Modal Pada Perusahaan Manufaktur Yang Terdaftar Di Bursa Efek Indonesia Periode 2012-2016. Jurnal Stie Semarang, 11(02), 15-30.

Smart, Scott B., William L Megginson dan

Lawrence J. Gitman. (2004). Corporate Finance. USA: SouthWestern College Pub.

Sugiyono. 2008. Metode Penelitian Bisnis, Penerbit Alfabeta, Bandung

Suharyadi dan Purwanto, 2009, Statitistika Untuk Ekonomi \& Keuangan Modern, Jakarta. Penerbit Salemba Empat,

Torang, S. 2012. Metode Riset Struktur dan Perilaku Organisasi. Bandung: Alfabeta.

Uffah, F., Mardani, R. M., \& Salim, M. A. (2019). Pengaruh Profitabilitas, Struktur Aktiva Dan Ukuran Perusahaan Terhadap Struktur Modal (Studi Empiris Pada Perusahan 
Manufaktur Sub Sektor Makanan Dan Minuman Yang Terdaftar Di Bursa Efek Indonesia Periode 20152017). Jurnal Ilmiah Riset Manajemen, $8(18)$.

Undang-undang Republik Indonesia nomor 20 Tahun 2008 tentang klasifikasi ukuran perusahaan.

Widarjo,W.danDoddySetiawan.2009.Peng aruhRasioKeuanganTerhadapKondis iFinancialDistressPerusahaanOtomot if,JurnalBisnisdanAkuntansi, $\mathrm{Vol} 11 \mathrm{~N}$ o2hal107-119

Wirawan, P. A. (2017). Pengaruh Struktur Aktiva, Profitabilitas, Ukuran Perusahaan Dan Likuiditas Terhadap Struktur Modal Pada Perusahaan Sektor Barang Konsumsi Yang Terdaftar Di Bursa Efek Indonesia Periode Tahun 2014-2015. Jurnal Pendidikan Ekonomi Undiksha, 9(1), 1-11.

Wulandari, N. P. I., \& Artini, L. G. S. (2019). Pengaruh Likuiditas, NonDebt Tax Shield, Ukuran Perusahaan Dan Pertumbuhan Penjualan Terhadap Struktur Modal. E-Jurnal Manajemen, 8(6), 3560-3589.

Yuliani, Y. Y. (2017). Analisis Struktur Modal Perusahaan Industri Makanan dan Minuman di Bursa Efek Indonesia. Ekspektra: Jurnal Bisnis dan Manajemen, 1(2), 81-88.

\section{PROFIL SINGKAT}

Brigitha Yulita Hoar Bau merupakan alumni dari Prodi S-1 Akuntansi STIE AUB Surakarta tahun 2020.

YuniatinTrisnawati D. K. W merupakan dosen di Prodi S-1 Akuntansi STIE AUB Surakarta. 